\title{
Improving students'writing performance by using personal photographs in writing descriptive text at MTs N 12 Tanah Datar
}

\author{
Yuni Kartika Fitri ${ }^{1}$,Hery Yufrizal ${ }^{2}$, Lilis Sholihah ${ }^{3}$ \\ English Education Study Program, University of Lampung ${ }^{1,2,3}$ \\ 1yunikartika6789@gmail.com
}

\begin{abstract}
The objectives of this research were to find out whether there is any significant improvement of the students' writing performance in descriptive texts and to investigate which aspects in writing skills that improve better after the implementation of a personal photograph in writing descriptive texts. The research was quantitative by using one group pre test and post test design. The population of this research was the first grades students of MTs N 12 Tanah Datar in the academic year 2020/2021. The sample of this research was VII F that consisted of 28 students. The instrument of this research was writing test. The results showed that there was a significant improvement of the students' writing performance after the implementation of a personal photographs in writing descriptive texts. It could be seen from the gain on pretest and posttest score. Based on the data, the mean value obtained in the pre-test was 69.32 , while the post-test was 84.43 ., so mean score increased 15.11 , in which t-value $>$ ttable $(12.93>2.052)$ or sig $(0.00<0.05)$. Furthermore, content was one of the aspects in writing skills that improve better after the implementation of a personal photograph in writing descriptive texts. The percentage of this aspect in the pretest was 20.995 while in the post test was 25.37., so the score increased 4.375. As a result, it can be concluded that personal photographs not only improved the students' writing performance but also all of the aspect of writing skills, because personal photographs can help students in developing their idea in writing descriptive texts. Personal photographs also can make students more active and easier when they want to describe something.
\end{abstract}

Keyword: Personal Photographs, Writing Performance, Descriptive Texts

\section{INTRODUCTION}

Writing is a skill that is required in written communication. As we know that people need information about various things such as social, political, economic, religious, or educational, therefore we need to learn to understand about writing a text that might help us share information with others easily. According to White (1986:10) writing is the process of expressing the ideas, information, knowledge, or experience and understands the writing to acquire the knowledge or some information to share and learn. Writing is one of the language skill that the students have to master. Students can use a variety of visual objects or things to help them express their ideas or feelings into written form easily.

There are some problems in writing that are most commonly found. First, the students difficult to start on their writing, as it is not easy to express what they have in mind using a foreign language. Second, the students often cannot develop their writing well due to their limitation in vocabulary and the last, students are concerned with the grammatical mistakes that they make in writing. This is according to Murcia (2001) writing is always found to be difficult either foreign learners or even native speaker. Based on the researcher's experience, students are confused when they start to write because of limitations in vocabulary and lack of understanding in grammar.

Based on the problems above, it is possible that the appropriate teacher materials and techniques affect the learning outcomes of writing. Teaching media hoped to be able to encourage them to start 
writing. One of the learning media that can be used is photograph. Photograph also like pictures that have high artistic value which is colorful and importantly they are rich with information. In this research, the researcher would try to utilize personal photograph of the students as a visual medium in teaching writing descriptive text. Personal photograph is one of media that can be used by English teacher to improve students' writing quality especially in descriptive texts. It is used as a medium to exercise their ability in writing. It can be said that personal photographs are valuable teaching aids in motivating students to start writing.

Based on the explanation above, we know that personal photographs were good for teaching writing descriptive text because personal photograph will make the students easier to express their idea into written form. So that, the researcher will investigate about 'Improving Students' Writing Performance by Using a Personal Photographs in Writing Descriptive Text at MTs N 12 Tanah Datar." Hopefully, this research could give some contribution for teaching writing especially in writing descriptive text.

\section{METHODS}

In this research, the researcher used one group pre test and post test designto find out the significant improvement of the students' writing performance after the implementation of a personal photographs in writing descriptive texts. The students at VII F class in MTs N 12 Tanah Datarin the first academic year 2020/2021 were selected as the samples of this research. The data were collected by using writing test.To analyze the data, the researcher drawing conclusions from the tabulated result of the pretest administering that is statistically analyzed using SPSS (Statistical Program for Social Sciences) version 20.0 for windows.

\section{RESULTS}

This research is directed to figure out whether there is any significant improvement of the students' writing performance after the implementation of a personal photograph in writing descriptive texts. This section will compare the different between pre-test and post test score as a result of treatment using personal photographs. The data were analyzed and interpreted using statistical software to provide the answer of the research question.

This study was conducted at MTs N 12 Tanah Datar West Sumatra on April $5^{\text {th }}-$ Mei $3^{\text {rd }}, 2021$. The researcher took one class randomly as the sample, VII F, then, which consisted of 28 students. Based on the learning rules that have been set by the headmaster of MTs N 12 Tanah Datar during this covid period, each class is divided into 2 shifts. So, the researchers follow these rules when conducting this research in offline. There were 3 phases in these research processes; pre-test, treatments, and post-test. Pre-test and post-test were conducted to find out whether the students' writing achievement increased compared to before and after the implementation of the treatments. The researcher conducted the research in 6 meetings, where 3 meetings were for shift 1 and vice versa.

Table 4. 1 Descriptive Statistic of Pre-test and Post-test

\begin{tabular}{|l|llllll|}
\cline { 2 - 7 } \multicolumn{1}{c|}{} & N & $\begin{array}{l}\text { Minimum } \\
\text { Score }\end{array}$ & $\begin{array}{l}\text { Maximum } \\
\text { Score }\end{array}$ & Range & Mean & $\begin{array}{l}\text { Std. } \\
\text { Deviation }\end{array}$ \\
\hline Pre-Test & 28 & 60 & 80 & 20 & 69.32 & 6.33 \\
\hline Post- Test & 28 & 72 & 98 & 26 & 84.43 & 7.91 \\
\hline
\end{tabular}


If seen as a whole, there was a significant improvement in the mean scores of 28 students between the pre-test and post-test. The mean value obtained in the pre-test was 69.32 , while the post-test was 84.43. In the pre-test, the lowest score was 60 points. Still, it was shown that the maximum score obtained by the student was 80 points which were categorized as a good score. These results implied that the students' writing ability was indeed varied. After the treatment, the lowest score in post-test was 72 points and the highest score was 98 points which indicated that is a very good score and better then pre-test. Furthermore, after comparing the data in the pre-test and post-test, it was found that there was a satisfactory improvement.

\section{Table 4. 2 Shapiro Wilk Normality Test}

\begin{tabular}{|l|lll|}
\cline { 2 - 4 } \multicolumn{1}{c|}{} & Statistic & Df & Sig. \\
\hline PRE-TEST & 0.943 & 28 & 0.128 \\
\hline POST-TEST & 0.948 & 28 & 0.177 \\
\hline
\end{tabular}

The table above shows that the result of the Shapiro Wilk test. The significance value was higher than $0.05(0.00<0.05)$ in pre-test and post-test which indicates that the null hypothesis $\left(\mathrm{H}_{0}\right)$ was accepted, meaning that population is normal distributed so assumption of t-test is fulfilled.

Table 4. 3 Paired Sample T-Test

\begin{tabular}{|lllllll|}
\cline { 2 - 7 } \multicolumn{1}{c|}{} & Mean & Lower & Upper & $\mathrm{T}^{*}$ & Df & sig. \\
\hline Post-test - Pre-test & 15.107 & 12.7 & 17.5 & 12.93 & 27 & 0.00 \\
\hline
\end{tabular}

The table above shows that the result of the analysis t-test one tailed using Minitab v18. The significance value was lower than $0.05(0.00<0.05)$ and $\mathrm{T}^{*}$ was higher than $\mathrm{t}$-table (see the $\mathrm{t}$ table in the appendix 9) it was $(12.93>2.052)$ which indicates that the alternative hypothesis $\left(\mathrm{H}_{1}\right)$ was accepted, meaning that there was a significant improvement of the students' writing performance after the implementation of a personal photographs in writing descriptive texts. Based on the table the researcher also concluded that with a 95\% confidence level, the improvement score after treatment using personal photographs (post-test) compared pre-test will be in range 12.7 until 17.5 point.

Table 4. 4 The Results of Pre-Testin Each Aspect

\begin{tabular}{|ccccc|}
\hline No & Aspects of Writing & $\mathbf{R}_{\mathbf{1}}$ & $\mathbf{R}_{\mathbf{2}}$ & Average \\
\hline 1 & Content & 20.57 & 21.42 & 20.995 \\
\hline 2 & Organization & 16.03 & 15.14 & 15.585 \\
\hline 3 & Vocabulary & 13.71 & 14.42 & 14.065 \\
\hline 4 & Grammar & 15.5 & 15.35 & 15.425 \\
\hline 5 & Mechanics & 3.53 & 2.78 & 3.155 \\
\hline
\end{tabular}

Notes:

R1: Rater 1 (The researcher)

R2: Rater 2 (The English teacher of MTs N 12 Tanah Datar) 
Table (4.6) shows that content was the highest score which means the students understand about the content of the descriptive text because the students already had the ideas about the topic they are going to write. While the lowest score was mechanic because most of them only focus on the content without paying attention to the mechanics, and they also do not understand how to use punctuation (mechanics) properly in writing descriptive texts.

Table 4. 5 The Results of Post-testin Each Aspect

\begin{tabular}{|ccccc|}
\hline No & Aspects of Writing & $\mathbf{R}_{\mathbf{1}}$ & $\mathbf{R}_{\mathbf{2}}$ & Average \\
\hline 1 & Content & 25.6 & 25.14 & 25.37 \\
\hline 2 & Organization & 18.39 & 24.39 & 21.39 \\
\hline 3 & Vocabulary & 16.35 & 22.53 & 19.44 \\
\hline 4 & Grammar & 19.78 & 20.57 & 20.175 \\
\hline 5 & Mechanics & 4.28 & 3.57 & 3.925 \\
\hline
\end{tabular}

Notes:

R1: Rater 1 (The researcher)

R2: Rater 2 (The English teacher of MTs N 12 Tanah Datar)

Table (4.7) shows that each aspect improves from the pre-test, especially in content which the highest score is 25.37. Meanwhile, the lowest score was in mechanics. It means the students improve their writing from the pre-test to the post-test in each aspect. It is because the students lacked in aspects of writing especially in vocabulary and mechanic but in the post test there is an improvement in each aspect. From the explanation above, the researcher concludes that the aspect in writing skills that improve better after the implementation of the personal photograph in writing descriptive texts was content.

\section{DISCUSSIONS}

After conducting the test and the treatment, the researcher analyzed and compared the score of pretest and post-test, the result showed that therewas a significant improvement of students' writing performance after the implementation of a personal photographs in writing descriptive texts. It can be seen from the score of pre-test and post-test. While the score in post-test was higher than the pretest. It implies that after the implementing the treatments, personal photographs can improve the students writing performance in descriptive texts. According to Ambarsary (2005) to grade one student of SMA Lab IKIP Negeri Singaraja proved that personal photograph could improve students' achievement in narrative writing. Furthermore, Dewi (2006) in her research which comparing two types of media stated personal photograph and autobiography in narrative paragraph found that personal photograph can be a power full teaching media which can be employed to help students to perk up their creative writing.

Next, the researcher found the aspect of writing skills that improved better after the implementation of a personal photographs in writing descriptive texts. Based on the result of pretest in each aspect of writing, content was the higher score than the other. The percentage of this aspect in the pretest was 20.995. while the lowest score was in vocabulary and mechanic. The percentage of each aspect was 14.065 and 3.155. Based on the result of post-test content still the higher score than the other aspect. The percentage of this aspect was 25.37. While the lowest score was in mechanic. The percentage of 
this aspect was 3.925. It means that the students understand about how to make a good descriptive text by using personal photographs after the implementation in the treatments. Based on the explanation above, it can be concluded that personal photographs can improved all of the aspect of writing, because personal photographs can make students more creative when they want to describe a person. In addition, the answer of the second research questions are content was the aspect of writing skills that improved better after the implementation of a personal photographs in writing descriptive texts, because content was the higher score than the other aspect.

There are several previous researches who conducted the personal photograph. According to Prayogo (2014), the result shows that personal photograph is one of the media that the teacher can use in teaching English especially in writing descriptive text, because personal photograph can give students motivated and also make the students easier when they are wants to describe something. Therefore, it can be said that there was a significant difference of the students writing skill in descriptive text after being taught by using personal photograph. Thedifferences between previous research and this research. In the previous research, the researcher used photograph in teaching writing recount text for second grade of junior high school. In this research, the researcher used personal photographs in teaching writing descriptive texts for first grade of junior high school.

Finally, it can be concluded that personal photographs not only improved the students' writing performance but also all of the aspect of writing skills, because personal photographs can help students to developed their idea in writing descriptive texts. Personal photographs also can make students more active and easier when they are wants to describe something.

\section{CONCLUSIONS}

Regarding with the research findings and discussions, the researcher concluded that there was a significant improvement of the students' writing performance in descriptive texts after the implementation of a personal photographs in writing descriptive texts. It is found that the implementation of using personal photographs can significantly improve the students' writing performance in descriptive texts.After conducting the research, the researcher found the aspects of writing skills that improved better after the implementation of a personal photographs in writing descriptive texts was content. It can be seen from the result score of this aspect in post-test increased from the pretest, and also content was the highest score than the other aspect.

\section{SUGGESTIONS}

By considering the result and the discussions, the researcher suggests for English teachers to use personal photographs as one of the alternative media to increase the students' writing performance. Personal photographs can help the students who still have the problem in writing a text. Besides that, this research was conducted by personal photographs in the seventh grades students of junior high school. Thus, for the next researchers can use personal photographs in different level of students, such as in senior high school in different grade.

\section{REFERENCES}

Ambarsary, E.B. (2005). Improving the First Year Students' Ability in Writing A Narrative Paragraph by Using Personal Photograph Based Writing Technique in Academic Year 2004/2005. (Unpublished Undergraduate Thesis): Institute of Teacher Training, Singaraja.

Celce- Murcia, M. (2001). Teaching English as a second or foreign language. Boston: MA.Heinle\&Heinle, a division of Thomson Learning.Inc 
Dewi, N.K.P. (2006). A Comparative Study Between Personal Photograph and Autobiography Techniques in Writing A Narrative Paragraph in The First Year Students of SMA Negeri 3 Singaraja In the Academic Year 2006/2007. (Unpublished Undegraduate Thesis): Ganesha University of Education, Singaraja.

Prayogo, Arief. (2014). The Effectiveness of Personal Photograph forTeaching Writing Descriptive Texts. (Unpublished Undergraduate Thesis): Universitas Muhammadiyah Purwokerto.

White, Fred D. (1986). The Writer Art, California: Wadsworth PublishingCompany 